
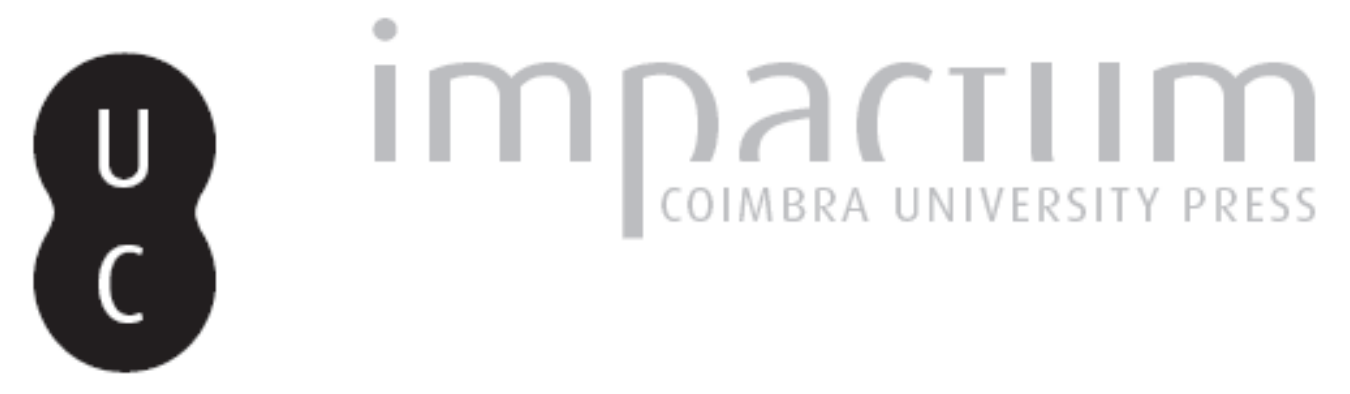

\title{
From bretton woods to the euro: critical considerations according to the hegemonic stability approach
}

\author{
Autor(es): Mistri, Maurizio
}

Publicado por: Faculdade de Direito da Universidade de Coimbra

URL persistente:

URI:http://hdl.handle.net/10316.2/39786

DOI:

DOI:https://doi.org/10.14195/0870-4260_57-2_27

Accessed : $\quad$ 26-Apr-2023 14:30:09

A navegação consulta e descarregamento dos títulos inseridos nas Bibliotecas Digitais UC Digitalis, UC Pombalina e UC Impactum, pressupõem a aceitação plena e sem reservas dos Termos e Condições de Uso destas Bibliotecas Digitais, disponíveis em https://digitalis.uc.pt/pt-pt/termos.

Conforme exposto nos referidos Termos e Condições de Uso, o descarregamento de títulos de acesso restrito requer uma licença válida de autorização devendo o utilizador aceder ao(s) documento(s) a partir de um endereço de IP da instituição detentora da supramencionada licença.

Ao utilizador é apenas permitido o descarregamento para uso pessoal, pelo que o emprego do(s) título(s) descarregado(s) para outro fim, designadamente comercial, carece de autorização do respetivo autor ou editor da obra.

Na medida em que todas as obras da UC Digitalis se encontram protegidas pelo Código do Direito de Autor e Direitos Conexos e demais legislação aplicável, toda a cópia, parcial ou total, deste documento, nos casos em que é legalmente admitida, deverá conter ou fazer-se acompanhar por este aviso.

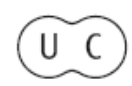




\section{UNIVERSIDADE DE COIMBRA}

FACULDADE DE DIREITO

BOLETIM DECIÊNCIASECONÓMICAS

HOMENAGEM AO PROF. DOUTOR ANTÓNIO JOSÉ AVELÃS NUNES

VOLUME LVII Tomo II
$\begin{array}{ccccc}2 & 0 & 1 & 4\end{array}$

Organizadores:

Luís PEDro Cunha

José Manuel Quelhas

Teresa Almeida

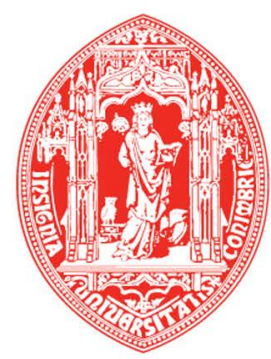

COIMBRA 


\section{FROM BRETTON WOODS TO THE EURO. CRITICAL CONSIDERATIONS ACCORDING TO THE HEGEMONIC STABILITY APPROACH}

\section{Introduction}

Criticisms have grown in recent years, especially in Mediterranean countries, of the financial and budgetary austerity policies at the base of the Maastricht Treaty. These criticisms are largely directed at Germany, seen as the custodian of an austerity policy that some European governments blame for the economic stagnation of their countries and the consequent increase in the levels of unemployment (Avelãs Nunes, 2013). However, precisely the Mediterranean countries, under French leadership at the negotiation stage of the Maastricht Treaty, were among the greatest proponents of European monetary integration as evidenced by the fundamental works of Kenneth Dyson and Kevin Featherstone (1999) and Harold JAMES (2012: 168), as well as an interesting book by a central banker, the Dutchman André SzÁsz (1999). Indeed, Germany was seen as the hegemonic country in the euro area; hegemonic because it was economically the strongest country, and as such, imposed the financial austerity policy on other countries. The creation of the euro has manifested some significant flaws and it would thus be interesting to investigate the reasons that 
led to the institutional disfunctionality of the single European currency. In the opinion of the author, these reasons must be sought primarily in the ways in which the negotiations took place for the creation of the euro. These negotiations were dominated by the relationship between France and Germany, whereby France considered itself the political Dominus of the new Europe while Germany aimed to strengthen its economy. France thought it needed Germany to have greater weight in international assizes and Germany thought it needed France for political legitimacy in the international arena. France could be seen as a type of aspiring hegemon while Germany as a de facto hegemon, but which it does not want to be.

After a brief examination of the concept of hegemony according to the science of international relations, I analyze its materialization from the end of World War I, showing how a country, in this case Germany, found itself playing the role of hegemon within a group of countries without having had the intention and also without having put in place a suitable project for this purpose. The history of the international monetary system, especially after the end of World War II shows that the rise of the hegemonic role of the U.S. in the West was determined by the unforeseen evolution of world political and military equilibria. In fact, from time to time, the creation of institutional equilibria was sought in relation to specific issues, drawing empirically on the concept of the decomposition of complex problems, as well illustrated by Thomas Schelling (1960).

This same method, which has the flavour of the heuristic approach adopted in institutional engineering, was used in the construction of the European integration process, first creating the European Coal and Steel Community (ECSC), not to provide a solution to the European coal and steel problems, but to solve a dangerous political dispute between 
France and Germany. The ECSC was such a success that it became the reference model for any future strategies of these European countries. The European Common Market (ECM) was inspired by this model, whose philosophy was not, however, political federalism but a type of technocratic functionalism. Regarding institutional models, when the countries of the European community began to address the problem of enlarging the coordination method to the sphere of monetary policy, a model was already available, namely, that which emerged from Bretton Woods. If it is true that elements of the negotiations of the Bretton Woods agreement are to be found in the European monetary integration process, it is also true that the overall context in which the Bretton Woods agreements were determined differed somewhat from the context in which the Maastricht Treaty was determined.

\section{Considerations on hegemonic stability}

During the formation of the international political economy, some works emerged that reflected the concept of hegemonic stability, an expression of the political, military and above all economic power of a hegemonic country. The concept of hegemonic stability has been the subject of extensive debate in international relations theory. In recalling this concept, those economists who are more sensitive to the issues of international political economy have somehow adapted it to their methodological needs, considering the influence on the political economy of the schools of thought inspired by the New Institutional Economy (NIE) and the Constitutional Political Economy (CPE). In particular, both the NIE and the CPE move away from some methodological assumptions of hegemonic stability typically developed by political studies, weakening the weight of the "power" factor of a State, to lean towards an approach that focuses more on the rules of the 
theory of cooperative games and is more in line with the economic methodology. In this sense, for example, so-called hegemonic cooperation (IsHiguro, 2003) can be evaluated, which is based on two fundamental assumptions. The first is related to the existence of a set of States with a liberal-democratic regime and similar 'strength', while the second is related to the manifestation of Nash equilibria in cooperative games. IsHiguro hypothesised that if the equilibria produced through interaction processes between politically liberal countries with equal strength they can be stable and the hegemony determined would seem to be mainly that of shared rules and not that of the power of a hegemonic State. Nevertheless, it follows that there is stability if, and only if, the individual States at the time of the negotiation have substantially converging preferences on the objectives and the actions to be taken. To also be considered is the problem of the correctness of the formulation of expectations of the results obtainable from agreed policy actions. Indeed, it is possible that at a later stage, one or more States could have second thoughts; the emergence of regret may depend on the cognitive limitations of the policy makers, limitations brought to light when dynamics and events occur that were not adequately taken into account.

The weakening of the concept of power plays an important role in how Robert KeOHANe (1984) interpreted the concept of hegemony, in view of the political events that took place after the Second World War. KeOHANE wrote (cit.p.137),

"Hegemonic leadership does not begin with a tabula rasa, but rather builds on the interests of States. The hegemon seeks to persuade others to conform to its vision of world order and to defer to its leadership. American hegemonic leadership in the post-war period presupposed a rough consensus in the North Atlantic area, and later with Japan, on the maintenance 
of international capitalism, as opposed to socialism... This consensus can be viewed, in Gramscian terms, as the acceptance by its partners of the ideological hegemony of the United States".

In short, the political leaders of Western Europe and Japan accepted the leadership of the United States that guaranteed safety and with it the construction of a model shared by societies, so as to suggest a community of countries that are in some way complementary, called on to share an international regime. It could be said that the hegemon rather than impose institutional solutions puts its strength and credibility to the service of a specific institutional design.

According to a vision in compliance with a certain conceptual extreme, which owes much to the doctrines of imperialism, a country is considered dominant when it is able to impose institutions to regulate international type relations that are more oriented to pursuing their own interests. It can thus influence the formation of institutions that regulate the internal life of the countries linked to it. A substantial conceptual chasm opens between a vision that is inspired by the theory of imperialism and a vision that is inspired by a liberal-democratic conception. Gilpin (2001: 93), who is a significant supporter of the theory of hegemonic stability, highlights that this theory has met with some strong criticisms from international relations scholars, such as, for example, Susan STRANGE (1987).

"Political criticism have ranged from denunciations of the theory as a defence or rational for American policies to the opposite idea that the theory predicted the absolute decline of the United States. No proponent of hegemonic stability theory, at least to my knowledge, has been motivated to justify American behavior; to the contrary, most were critical of the 
self-centered and irresponsible American behavior that begin in the 1960s, if not earlier" (ibid: 93-94).

The theory was also criticised by liberal-democratic scholars, according to whom it is possible for some countries without a hegemonic vocation to identify a cooperative solution to the problems associated with the establishment and maintenance of a liberal economic order. GILPIN in this regard wrote,

"although it may be possible to create a stable liberal international order through cooperation but without a hegemon, this has never happened and with no counterfactual example neither the theory nor his critics can be proved wrong" (ibid: 93).

Gilpin had the conviction that a liberal international economy required a hegemon that respected liberal economic principles, as did Great Britain in the nineteenth century and the United States in the twentieth. Eichengreen (1989) was tepid towards Gilpin's position and claimed that empirical evidence to confirm the theory could not be found. In defence of the theory, Gilpin noted that the attitude of Eichengreen seemed to be based on the assumption - which Gilpin considered mistaken - that the hegemon must be an imperialist power that imposes its will on other countries. However, in further developments of Eichengreen's analysis, according to GILPIN (ibid: 95) significant acknowledgment could be found on the relationship that may manifest between the start of international cooperation processes and the action of a hegemonic power, but not necessarily imperialist. In a sense, a hegemonic country can be seen as that which obtains consensus on certain institutional choices and acts as the guarantor of the stability of such institutions. 


\section{The decline of British hegemony}

Just above I mentioned that the Bretton Woods system was able to represent a conceptual framework and method to launch the process of European monetary integration. Precisely for this reason, prior to addressing the issues most closely related to the euro, it would seems appropriate to consider the matter discussed at Bretton Woods in an attempt to ensure, at least in the western world, a sufficiently stable international monetary and financial system that was capable of fostering greater integration between those economies whose ties had been broken by the war. Reference to what happened at Bretton Woods serves as a reminder that on the negotiation table at the time, especially between Britain and the U.S., were some issues that in part re-emerged during the negotiations for the creation of the euro. Among these issues is the identification of the country that had to assume the burden of the balance of payments (EICHENGREen, 1996: $96 \mathrm{ff}$.). Then, as now, the issue on the agenda was that of reconciling the stability of the monetary yardstick with the fight against unemployment.

Among economists, in the period between the two World Wars, the prevailing opinion was that the stability that the international monetary system had enjoyed in the nineteenth century had been assured by the adoption of the gold standard, a monetary system anchored to gold. It was widely believed that gold anchorage would have avoided unwanted inflationary pressures and unfavourable foreign exchange fluctuations. At that time, high value was assigned to price stability as an instrument that would ensure economic development. Meanwhile, the safeguarding of national gold reserves would be assured by the adoption of "deflationary" measures and interest rate manoeuvring. Nevertheless, the opinion was somewhat widespread that the stability of the gold standard 
in the pre-war period derived in part from the credibility of the behaviour of countries that were part of the system (CASPRINI, 1995: 35). Numerous scholars believed that the possibility of the system functioning according to expectations rested on the behaviour of England. This country, through appropriate monetary manoeuvres, would have ensured stability, thanks to the centrality of the international financial market in London. In short, in the nineteenth century, England, for a certain period of time, was the hegemonic country, capable of ensuring the stability of the international monetary order. KéBABDJIAn (1999: 109) observed that up to the First World War, the system worked by virtue of the hegemony of England, which governed the financial market using primarily the instrument of interest rate manoeuvres.

The consequences of the First World War were devastating in that the war brought about the rapid growth of public spending of belligerent countries and the explosion of public debt, shattering the defences represented by the gold standard. These defences would prove unsuitable not so much when called on to confront economic type crises but situations of systemic type structural breaks. The first post-war period saw several attempts to restore the gold standard, which in reality history would have archived. England especially tried to anchor the pound to gold again in 1925, with effects that quickly proved disastrous, if for no other reason than the overvalued pound, fostering the growth of unemployment. In 1931, Britain devalued the pound and suspended gold conversion, ceasing to be the guarantor of the stability of the international monetary system.

Under exceptional economic conditions such as those of the First World War, the gold standard proved to be unsuitable to simultaneously ensure the stability of the monetary yardstick and an adequate level of employment. Britain's abandonment of the gold standard was welcomed, for example, by 
Keynes who had long fought for a different system of rules from those needed for the adoption of the gold standard. In his A Tract on Monetary Reform (1923), Keynes considered what in his opinion should have been an optimal monetary policy, at least for a country like England, linking domestic monetary policy to foreign monetary policy. Concerning this link, Keynes (1923) questioned whether it would be preferable to maintain exchange parity (no longer with gold, but with the dollar) or maintain the stability of domestic prices, avoiding those deflationary strategies that would have been the consequence of the first option. Keynes was clearly in favour of the second option. This implied that national monetary policy should be manoeuvred, with a degree of discretion, by the central bank whose aim should be to avoid deflation and at the same time control the employment dynamics. Moreover, rejecting a return to the gold standard was motivated by Keynes's fear that in this way, England's economic and monetary policy would be conditioned by FED strategies, losing what Keynes considered the necessary freedom of manoeuvre to implement active supply policies.

To be noted is that Keynes was convinced that abandoning the gold standard would not lead to the various countries resorting to competitive devaluations. In fact, abandoning the gold standard led to a race to competitively devalue the European currencies and the dollar, partly because the economically stronger countries were unable to give life to serious cooperation between them. However, while World War II was taking place, it seemed necessary, at least in the eyes of the Western powers, to set up an international monetary system that had as its goal the reconstruction of the network of trade relations, essential in accelerating a difficult economic recovery. In order for international trade relations to be re-established, especially in Europe, some basic conditions related to the governance of the international monetary sys- 
tem were called for. One of these was that the European countries would be able to restore the convertibility of their currencies and that such convertibility was accompanied by sufficient, although not absolute, exchange rate stability. Furthermore, let us recall that to relaunch their economies, European countries needed to obtain robust credit facilities, especially from the U.S., the only country able to help finance the reconstruction of European economies.

\section{Bretton Woods. From English hegemony to U.S. hegemony}

In July 1944, the famous international conference was held at Bretton Woods in which delegates from 44 countries tried to lay the foundations for a new international monetary and financial system. It was there that two different conceptions of the international monetary order encountered each other and clashed. The two notions to which I refer is that of the U.S., whose delegation was led by Harry Dexter White, and the British, were the most influential member of the delegation was John Maynard Keynes (Cesarano, 2006; Gardner, 1956; Steil, 2013). The end of WWII marked the disruption of the old economic and financial world equilibria, where England still had some role in its governance, albeit waning, and the beginning of a new phase characterized by the emerging hegemony of the U.S. in an international political and economic situation where the future evolutionary processes were not known with certainty, especially after the substantial abandonment of the gold standard.

As previously mentioned, the period between the two World Wars was marked by the end of the gold standard and the replacement of the old international monetary order with a "new" order based on a generalized propensity towards autarky. Roy Harrod (1951, chapter 8) recalled that Keynes' 
battle against the gold standard had been in act since the end of the First World War. Keynes was aware that a return to the gold standard was no longer possible and considered the problem of defining an active monetary policy within the framework of a renewed system of international trade. As mentioned, England, having re-established the gold standard in 1925 would abandon it in 1931 in the aftermath of the financial and economic crisis of 1929; a crisis that led to the fundamental problem of unemployment in both the U.S. and in European countries. KeYNES interpreted this theme in a different way compared to those that, at least formally, were inspired by the economic policies of the major European countries and the U.S. during the hegemony of the gold standard. If Keynes was trying to harness the "beast" of deflation and with it that of unemployment, the U.S. feared that at the same time the other "beast", namely, inflation would be released.

A recent book by Benn STeIL (2013) is entitled The Battle of Bretton Woods, an appropriate title because at Bretton Woods a real duel took place between two unaligned conceptions of the international monetary order that would have to be rebuilt. These two different conceptions reflected the non-converging and in part short-term interests of the U.S. and Great Britain but they also reflected the longer-term concerns of these two States. However, we must also consider that the delegations of the countries at Bretton Woods were called on to insert the rules of the new international monetary system in the new international regime that was to be built. To be first noted is that the fundamental concerns of England and the U.S., rather than aiming for the reconstruction of an international monetary system, primarily aimed at the reconstruction per se of a system of international trade based on multilateralism. As expected, awareness existed of the fact that no system of international trade could be created 
in a serious way without building a credible international monetary system.

In this perspective, KeYNES proposed his Clearing Union project. Although Harrod believed that the Keynes project was intended to respond to the ideas of the U.S. State Department, very strong concerns remained towards a system that in White's opinion would have discharged the burden of adjustment of trade balances of European countries in deficit on the U.S. The Clearing Union project that Keynes drafted emphasized the importance of having an international monetary instrument that all countries would find acceptable in order to avoid blocked accounts and bilateral compensation. Keynes, in this regard, proposed giving life to an international unit of account, the Bancor, which was not subject to large fluctuations caused by the policies of individual countries in terms of gold reserves but was governed by the current needs of world trade and capable of deliberate expansion and contraction to override inflationary and deflationary trends in effective global demand (Harrod, cit.).

Keynes' idea was to create an International Clearing Bank (ICB) whose function would be similar to that of an ordinary bank except that while the customers of an ordinary bank are individuals or companies, ICB customers would be the central banks of member countries. Hence, this would be a generalization of the essential banking principle; a principle consisting in the necessary equality between debt and the availability of credit of the bank's depositors. Countries that had a balance of payments surplus with the rest of the world, seen as a whole, would have a credit account with the ICB, while those in debt would have a debt account at the ICB. This would give a line of credit to the debtor countries based on their amount of foreign trade.

The instrumentation of the "Keynes Plan" was certainly more complex and ambitious than the "White Plan". Howe- 
ver, from a cognitive point of view, the risk was that the expected results would be less certain and in some way without limiting the development of possible opportunistic behaviours of some ICB member States. In this regard, GARDNER wrote,

"the Clearing Union would make large overdraft facilities available to its members, facilities related to their pre-war share of the world trade... Since no limits were set on the value of individual credit balances, the Union provided a complete clearing mechanism. Surpluses and deficits in the balance of payments of member countries would be reflected in credits and debits on the book of the Union, expressed in 'bancor', an international unit of account. With these vast reserves of liquidity at their disposal, members would be able to eliminate all exchange restrictions on current account, maintain stability in their exchange rates, and pursue policies of domestic expansion without fear of the consequences of their foreign balance" (GARDNER, 1956, p. 79).

However, Gardner highlighted an aspect of the Keynes plan that specifically concerned the Americans. That is to say, "the large overdraft facilities would certainly go far to assure the members that policies of domestic expansion would not be inhibited by deficits in their balance of payments" (ibid.). If in some way the Keynesian treatment could entail the adoption of inflationary policies, the question then would be whether this pressure would in turn be a factor of further trade imbalances.

Following Eichengreen (1996: 75 ff.), the Keynes and White plans differed largely in the obligations of the creditor nations, in the degree of flexibility of exchange rates and capital mobility. KeYnes believed it possible that nations could vary exchange rates and/or impose restrictions on foreign exchange and trade, while the White plan foresaw a fixed 
exchange rate system regulated by an international body. One of Keynes' key concerns was avoiding that the deflationary policies implemented mainly by deficit countries would have negative effects on employment levels in both deficit and surplus countries. To tackle this problem, Keynes proposed that debtor countries would be granted the necessary funding to rebalance their balance of payments (with conditions that became increasingly unfavourable to the growth of debt), together with considerable exchange rate flexibility (EICHENGREEN, cit).

\section{The U.S. and minimizing the regret of the hegemon}

The above-mentioned position was a difficult knot to untie. White manifested the fear that if the U.S. were to permanently play the part of creditor country, it would have been obliged to fund all the drawing rights of other nations, taking on unlimited liabilities (Harrod, 1951) and hence the U.S. opposition to the Clearing Union that KeYnES conceived. Regarding this point, EICHENGreEN (1996: 97) noted that the U.S. would find itself at least in part in the position of the Bundesbank in 1978 during negotiations for the creation of the European Monetary System, inasmuch as the German central bank was opposed to a system that would oblige countries with a surplus balance of payments to indefinitely sustain nations with weak currencies. Thus, returning to Bretton Woods, the U.S. obtained the removal of the formula on unlimited liability of surplus countries to replace it with a limited liability formula. The U.S. then posed the question of the commitments that structurally indebted countries would assume.

I conclude this summary on the Bretton Woods agreements by emphasizing that during these negotiations a key issue emerged in relation to the role that a hegemonic coun- 
try could assume to ensure the governance of a given international regime. What the UK asked the U.S. was to finance the trade deficits of economically weak countries. They wanted to create a stable institutional system based on the role of the U.S. as guarantor of the stability of the system itself, starting with the assumption that the U.S. would continue to play the role of creditor country. However, it was precisely the evolution of the international economic and financial system that demonstrated the weakness of the assumption that the U.S. would be creditor country par excellence. Indeed, after the start of the Korean War, the position of the United States changed from creditor country to debtor country (CATALANO, 1972: 172) with the transfer of gold reserves from the U.S. to some European countries, Great Britain first in line. These flows were accompanied by the emergence of surging pressure for parity of the major European currencies against the dollar. The U.S. trade deficit provided liquidity to the international monetary system, making it difficult, however, for the U.S. to maintain parity, fixed at the time, between the dollar and gold. If the structural parameters of an international monetary regime are not stable as they are exposed to the consequences of uncontrollable external dynamics, it becomes difficult to believe that a system of rules designed to ensure the governance of that given international monetary regime can remain stable. The question that arises is whether and to what extent a country, even if politically and militarily "hegemonic", can accept binding financial commitments in a context of structural instability of the external environment and the balance of power between the economies of partner countries, power relations that vary over time.

During the Bretton Woods negotiations and in the subsequent decade, the role of the U.S. as guarantor of the multilateralisation of international trade emerged and the 
consequent functionality of an international financial system whereby a reasonable convertibility of currencies could be guaranteed. In reality, the system that resulted from Bretton Woods appeared mainly oriented to solving short-term imbalances in the balance of payments through a form of cooperation between States, leaving individual national governments the task of working on the structural causes of the imbalances of the specific trade balances. This distinction is not insignificant because from this stems the nature and scope of commitments that could and/or should have been made by States that were structural debtors and those that were structural creditors. The nature of these commitments belongs to the sphere of negotiations between States that can find a point of agreement on the space of possible actions. According to game theory, players can find agreement within the set of values of the efficient frontier of the bargaining problem (Dixit, SкEATH and ReILey, 2009: 698).

These are, of course, estimated values. However, I hypothesize that the construction of a new monetary regime is an economic and social engineering choice whose materialization is highly uncertain, in the same way as there is no certainty that the results actually achieved will be consistent with the pre-determined goals. Due to this uncertainty, the countries that can play the role of hegemon are unwilling to make commitments when the consequences are not entirely under their control. There is no doubt that at the end of the Second World War, the U.S. agreed to assume certain commitments expected of a hegemon. It did so despite rejecting the Keynes project that in its eyes would have forced it to assume commitments it considered potentially unlimited but accepting to engage in an aid plan, which went under the name of the Marshall Plan. The Marshall Plan committed the U.S. within substantially defi- 
ned quantitative and temporal limits that would therefore not have exposed them to unlimited financial commitments. From this event, we can draw the conclusion that the strategies that a hegemon can accept are influenced by what one might call a type of 'principle of minimizing the expected regret'. However, it seems to me that the considerations that Cesarano (2006: 19) advanced are worth sharing, according to whom what the Bretton Woods negotiators attempted was unwise since it would have created an inherently unstable system.

\section{Towards a European monetary regime. From Bret- ton Woods to the Werner Report}

The issue of the construction of the international monetary system at Bretton Woods has been evaluated, albeit briefly, from the point of view of the roles assigned to countries with balance of payments deficits and those with balance of payments surplus, highlighting the problem of the crucial role played by a hegemonic country. These are issues that, to a large extent, reappeared in the case of European monetary integration, punctuated by a series of projects and initiatives, starting from the failures of the first attempts to coordinate the monetary policies of the Western European countries to arrive at the euro. At this point, it seems legitimate to question the relationship between the Bretton Woods institutions and the positions that in terms of exchange rate systems became prevalent in Western Europe. In this regard, Emmanuel Apel (1998: 25) wrote,

"The decision, taken at Bretton Woods in 1944 to establish an international monetary system based on fixed exchange rates was in line with Continental European's general dislike for flexible exchange rates". 
Although the governments of Western European countries had little sympathy for a flexible exchange rate system, it should be noted that at the time of drafting the Treaty establishing the MEC, the monetary question was not on the agenda. This was because the obligations in monetary policy matters did not go beyond a generic coordination of monetary policies. However, the emergence of the question of some form of monetary integration dates back to the early ' 60 s.

The aversion towards a system of flexible exchange rates was determined in Western Europe for at least three fundamental reasons, evidenced, for example, by Francesco GiavazZI and Alberto Giovannini (1989: 1). The first reason was the evaluation of the experience of a system of flexible exchange rates in the 1919-1926 period. The second reason was the presumed negative impact of flexible exchange rates on trade and foreign investment flows and the effect on relatively open European economies. The third reason was the difficulty of managing the Common Agricultural Policy (CAP) implemented by the European Community with a system of flexible exchange rates. André SzÁsz (1999: 12) noted that at that stage, monetary integration was seen by the Commission as a 'technical monetary' problem corresponding to the functioning of the Common Agricultural Policy to which France was particularly sensitive; as a catalogued 'technical monetary' problem, the wider implications of both an economic and political order were underestimated.

Against this, there was still the difficulty that had previously emerged at Bretton Woods of determining which among the countries with balance of payments surplus and those with a balance of payments deficit should assume the role of guarantor of the adjustments of the imbalances. France and much of the Commission opted for inflationary type policies, while the Netherlands and Germany desisted a choice 
that could trigger inflationary impulses that could be transmitted from one country to another. Among other things, in the second half of the " 60 , gaps were growing between the real economies of European countries and with these the imbalances between the balance of payments, requiring a closer evaluation of the relationship between the functioning of the single national economic systems and that of a potential European monetary system. There were two different schools of thought at the time. That of the 'economists' who believed that the equilibrium of the balance of payments had to be achieved through improving the efficiency of the economies of countries with the highest inflationary propensity; and that of the 'monetarists' (which had nothing to do with the Chicago School) that opted for policies based on deficit spending. The project of the Frenchman Raymond Barre was presented in this context, which in part recalled the logical framework of the Bretton Woods system. In Barre's project, exchange rate stability was essentially seen as a problem of a monetary nature, while the Netherlands and Germany aimed at overturning the terms of the problem in the sense that imbalances in the balance of payments were seen as a result of structural differences in the governance of national economic systems.

At the Hague Summit in December 1969, on the initiative of the German Chancellor Willy Brandt and the French Georges Pompidou, the development of monetary cooperation was discussed based on the harmonization of economic policies. Political factors of an international order, such as the by now definitive weakening of the dollar and especially the crisis of the French economy, lead France to believe that the destabilizing forces of the dollar had to be counteracted with a stronger coordination of monetary and economic policies of European countries, encouraging Brandt to strengthen agreements with France. 
After the Hague Summit, namely in March 1970, the Commission submitted a report to the ECOFIN Council entitled $A$ Plan for the Phases Establishment of an Economic and Monetary. This plan proposed - with 'a certain superficiality' as concerned André Szász, an important negotiator of the Dutch Central Bank (SzÁsz, 1999: 34) - a three-stage approach to economic and monetary union, which was supposed to start in 1971 and last for around ten years. The report proposed that in the last stage, the margins of fluctuation of the currencies of member countries would be eliminated thereby irrevocably setting parity. Based on this plan, the Council asked a panel of experts chaired by Pierre Werner to explore the question of the implementation of economic and monetary union in stages. The document that resulted, known as the Werner Report, foresaw the progressive elimination of currency fluctuations in countries belonging to the Community and, in the final stage, the introduction of fixed and irrevocable exchange rates between these currencies, and the full liberalization of capital movements. In addition, the report proposed the creation of a European Fund for monetary cooperation as the potential core of a future European Central Bank. In sum,

"the definitive text of the Werner Report was a compromise between two opposing schools called the 'monetarists', represented by the French and the Belgians/Luxembourgeois, and the 'economists', represented by the Germans and the Dutch" (APEL, 1998: 33).

The 'monetarists', in the wake of the now dominant technocratic formulation of communitary bodies, believed that the single currency would become an identifying symbol, a type of European federator. Numerous policy makers in Western Europe saw monetary integration as a step towards 
political integration (PADOA-Schioppa, 2004: 203 ff.). By contrast,

"the 'economists' believed that an essential prerequisite to major progress towards institutionalized forms of monetary integration, involving irrevocable fixed exchange rates and leading ultimately to a single currency and a single monetary policy, was a high degree of coordination and convergence of economic policies. According to this school, a monetary union can only be the crowning achievement of a gradual process that would harmonize economic policies between the Member States" (Apel, 1998: 33).

Indeed, in a type of compromise logic, the Werner Report spoke of parallel progress in terms of economic and monetary union. Specifically, the Werner Report avoided highlighting that, in fact, substantial temporal asymmetry existed in the rate of change of monetary institutions, once decided, and that of institutions that govern the real economy, which were much slower and conditioned by strong path dependencies.

Particular attention should be paid to the reaction of a substantial number of academic economists to the Werner Report, especially in North America, (Maes, 2002: 35). Scepticism was expressed, for example, by Fleming (1971), by Corden (1972), by Johnson (1972), by Dehem (1972). This scepticism was also based on the ascertainment that European countries had different national systems of preferences in terms of economic and financial policies (Feldstein, 1997b). These different systems of preferences, of norms, corresponded to different tradeoffs in the relationship between inflation and unemployment. As well known, this relationship is the basis of the Phillips curve, which at that time had an important role in macroeconomic analyses and economic policy praxis. On the other hand, as noted by Giovanni MaGnifico (1971: 13), to also be recognized is that each country had 'a 
national propensity to inflation'. The different national propensities to inflation reflect the multiple forces of a given economic system, amongst which are those that are expressed through institutions of a social and political order. Indeed, a specific action in the field of economic and financial policy is almost always reflected in the consolidated social equilibria expressed through a system of social institutions, often with considerable inertial force. The inertial forces referred to affect the performance of economic systems and when these are considerable, they can transform the expected complementarity between certain institutions into actual conflicts between these institutions. Thus, the presence of such conflicts can be read as an expression of the fact that an economic and monetary area is not an optimal currency area in the sense of Mundell (1961). If Western Europe were not an optimal currency area, then a monetary union would force a country to accept a trade-off between unemployment and inflation that would be considered sub-optimal (MAEs, 2002:35).

\section{The turbulent seventies and the revival of European monetary integration}

The Werner Plan put the discussion of some concepts on the table such as the coordination of budgetary policies and the construction of a supranational body in terms of monetary policy. However, these concepts were not rendered operational also because at the beginning of the seventies the Bretton Woods system collapsed. The end of the monetary regime created at Bretton Woods inevitable brought about the waning of the idea that such a system could be based on the role of a hegemonic country. Meanwhile, after the end of the Bretton Woods system, the transition to a system of flexible exchange rates meant entering an institutional terrain that lacked solid points of reference. Some institutional formula 
was sought to restore minimal order to the international monetary system.

"In July of 1972 the governors of International Monetary Fund set up the Committee of Twenty (C-20), composed of representatives of each of the twenty country groups represented by an IMF executive director, to prepare proposals for reforming the par value system" (EICHENGREEN, 1989: 140).

The international currency market now saw the U.S. move from the role of a positive trade balance country to that of a negative trade balance country. The position of the U.S. in the reorganization of the international monetary system thereby assumed nuances that were closer to Keynesian theory than those of the Chicago school. The U.S. thus moved towards a system of flexible exchange rates, while Western European countries were still looking for a way to reduce the variability of exchange rates. Once again, the question was raised of the role assigned, or otherwise, to countries with surpluses in their trade balances. These countries did not want to be forced to correct their positive balances with inflationary measures and opposed the idea of using IMF reserves as a means of bridging the dollar chasm. In other words, they did not want the task of guarantors of the deficits of others.

However, in April 1972, the central bank governors of the six member countries and Denmark, Ireland and the United Kingdom signed an agreement to fix the bilateral parities and maintain the exchange rate within a total fluctuation band of $5 \%$ around such parity, launching the so-called European Monetary Snake. However, the snake had a difficult life because dynamics manifested that caused a flutter in the system, highlighting the differences between the economic and financial policies of member countries of 
the agreement. In particular, the two major oil shocks of 1973 and 1974 led to a rapid process of high inflation in Europe combined with strong growth in the levels of unemployment in most European countries. These two dynamics, albeit shared by European countries, varied in intensity from country to country, thereby accentuating the divide between the economies of the various countries of Western Europe. At the same time, further differences manifested in national preferences on the possible monetary policies in Europe. France, after Italy, exited from the snake and in order to resume the initiative in relation to a European monetary system called for the surplus countries to be involved in the adjustment policies.

The French position was rejected by Germany and Holland.

"More fundamentally, divergences about policy priorities between the European countries, especially France and Germany, came to the surface and led to wide differences in inflation rates and exchange rate turmoil in Europe" (MAEs, 2002: 83).

However, on the Franco-German initiative in March 1979 life was given to the European Monetary System (EMS), which differed from the snake in the fact that the fluctuation of currencies would not have occurred within a grid of bilateral parity but on the exchange rate with a currency basket (the ECU) representative of all the currencies of member countries. The weaknesses of the EMS were highlighted by, amongst others, SzÁsz (1999: 64) who pointed out the problem that the common monetary policy was not accompanied by a common economic policy. That is to say, while attempting to strengthen currency type constraints, very little was said about the economic and budgetary 
policies of the various national governments. In this regard, SzÁsz wrote (cit: 64-85),

"participants entered into the European Monetary System in 1979 without having either a common strategy or common tactics. They do not agree on priorities for their domestic policies or on constraints to these policies; there were no common guidelines comparable to the convergence criteria in the Maastricht Treaty a decade later. They did not agree on 'rules of the game' in managing the EMS".

Under these circumstances, it did not take long for the EMS insufficiencies to come to light.

In the absence of serious efforts of partner governments in matters of economic policy, the asymmetries between the economies of the European countries led the governments of economically weaker countries to change the parities from time to time, effectively transforming the EMS into a system of adjustable fixed exchange rates. In practice, several realignments between European countries took place; in particular, Mitterrand's France enacted an inflationary policy, weakening the French franc compared to the German mark that gradually acquired a central role (Pifferi and Porta, 2006: 10). In France, the contrast heightened between Jacques Delors, the finance minister, and Mitterrand on the contents of the economic policy. Delors believed that France needed to remain in the EMS and at the same time convince Germany to bear some of the costs of adjustment even through a revaluation of the mark. The French position tended to privilege the role of purely monetary policies, although with short-term effects, with respect to the German position that continued giving priority to economic and budgetary policies. The conflict between France and Germany in the sphere of European monetary policy was, in fact, a sort of constant. The paths of the two economies were now divergent; faced with such divergence, 
France did not want to surrender to devaluing the franc, to the extent of asking that its currency be revalued by Germany.

In January 1988, the French economy minister, Edouard-Balladour - anticipating considerations that would find more completeness in a report that would take the name of the president of the Committee who drafted it, namely, Jacques Delors - proposed that life be given to a single currency, with a European Central Bank, to complete the European single market that was to begin in 1992. In practise, Balladour's move was seen as an attempt by France to absorb the force of the German mark and water down the German currency in a set of European currencies. The reaction of the Bundesbank was prudent, not to say reticent, as the German side believed that the single currency should be the culmination of a long process of economic integration.

However, in June 1988 the European Council created a committee chaired by Jacques Delors, who was entrusted with the task of studying the transition to economic and monetary union between the member countries. In April 1989, the Delors Committee presented a report that included three action steps as well as identifying the objectives and conditions to participate. The goal was to irrevocably fix the exchange rates between European currencies and then arrive at a single currency. With regard to the Delors Report, PADOA-SchiOPPA (2004: 136) observed that this report, while incorporating the major terms of the Werner Report, went beyond the goal of a single monetary policy. The third stage was that which indicated, following a modification of the Treaty of Rome, the purpose of the creation of a European Central Bank.

\section{International monetary regimes and hegemonic stability. The case of the euro}

From the analysis of the international cooperation processes emerges that certain agreements, especially those invol- 
ving stringent commitments between States, are possible, at least theoretically, if these States are sufficiently close, both geographically and culturally, sharing common ideals and political values. This could be the case of the EU, although a fault line manifested between two groups of countries that showed different preferences in terms of economic and financial policy. In this case, it becomes difficult to speak of hegemony of one State over others, while the contrast between the national preference functions strengthens the role of the nation-State whose institutions should be positioned as complementary to the supranational (AокI, 2001: $267 \mathrm{ff}$ ).

International monetary relations can be seen as a sub-system belonging to the more general system of international economic relations based on the rules that the various national governments have, at times individually and more often collectively. In the case of EU countries, the need to modify existing institutions became evident to provide, at least in some matters, an institutional framework consistent in all member countries. However, a new institution, even if attempting to homogenize the governance of a particular matter, may enter into a logical/operating conflict with all the other institutions that ensure the governance of inter-connected or inter-dependent economic and financial matters. Such is the case of the system composed of institutions that regulate particular economic and financial matters. A system that, in turn, can be regarded as composed of two sub-systems, namely that of institutions that govern 'internal' economic and financial matters and those institutions that govern economic and financial issues related to international relations. In addition, in the case of the EU, the sub-system of the institutions that govern international type economic and financial matters must be divided into two further sub-systems, namely, the institutions that govern economic and financial matters relating to relations between EU Member States and 
the institutions that govern economic and financial matters relating to relations between the EU and countries outside of it. The distinctions listed above, as has been said, are ideally inspired by a complementary principle, but this does not eliminate the possibility that a sub-system affects another sub-system.

This is a specific conceptual scheme of the experience in relation to the European integration process, particularly with regard to the European monetary integration process. The latter was substantially supported by France and by Germany with some methodological specifications, almost giving a tangible form to the Ishiguro model. However, in the case of European monetary integration, precisely the lack of an effective hegemonic made an institutional process such as that of the euro difficult. Therefore, the argument that I espouse is that the birth of the euro took place without the leadership role of a true hegemon, but under the pressure of France that could not be hegemonic, although aspiring to be such. On the other hand, numerous works emphasize the hegemonic role of Germany in determining the philosophy and structure of the Maastricht Treaty and thus the architecture of the European monetary system.

Especially in southern Europe, some politicians and scholars believe that the economic hegemony of Germany is interpreted as an expression of a vision of free trade imposed by using some kind of force. Some critical writings in respect of the euro and its rules state that these were sought by Germany to stifle the peripheral economies in Europe (Kouvelakis, 2012: 16). Germany was accused of wanting to put a kind of ideology at the heart of the construction of the euro, namely, that of price stability, in some way aimed at conquering economic hegemony in the European market, at the cost of the progressive marginalization of 'peripheral' countries. 
From credible historical reconstructions such as that of Dyson and Featherstone (cited above) and that of André SzÁsz (1999), the reality was rather different. At the signing of the Maastricht Treaty, there was little enthusiasm in Germany for the eventual entry, for example, of Mediterranean countries. Central and northern European countries feared that the Mediterranean countries would "export" the inflationary pressures that had long characterized their economic policies to central and northern European countries. At the same time, the countries of central and northern Europe feared being asked to contribute to financing the budget deficit of Mediterranean euro countries.

\section{The role of France as "aspiring hegemon"}

Also in 1989, in relation to the possibility of creating a European Central Bank, Mitterrand (as reported by Reuters) highlighted the political need affirming that the strongest currency in Europe was that of Germany. Mitterrand therefore questioned whether the French had to live in an area of the mark where only the Germans could express themselves. Mitterrand said he would prefer an assembly, a permanent conference of the different European governments where France could have its say on all aspects of economic policy.

Mitterrand's position showed the difficulty of the political relationship that was establishing between the two most important countries of Western Europe. A difficulty exacerbated by the loss of France's economic weight in relation to Germany's increasing economic weight. In this context, Mitterrand claimed a sort of continuity with the action of Charles de Gaulle, based on the desire to be free of U.S. military protection and the economic conditioning imposed by the role of the dollar. At the same time, Mitterrand developed pressing diplomatic action in respect of Germany, 
beginning with its chancellor, Helmut Kohl. Mitterrand's political objective was to restore European centrality to French politics, making France a type of engine of European integration. The Europeanization of money served France to contrast the dominance of the dollar and to neutralize the political role of the mark.

Dyson and Featherstone (1999) described in well-documented detail how Mitterrand's and the French government's strategies developed. A strategy designed to overcome the distrust of Germany, and especially of the Bundesbank, in respect of a process of monetary unification that the German side considered premature. In fact, in Germany it was believed that monetary unification should develop in parallel with political unification and, especially in the Bundesbank, it was thought that monetary integration should follow political integration. Conversely, France argued that monetary unification should take place before political integration and would in fact accelerate political unification. Mitterrand was holding the Europeanism flag behind which was, however, the more concrete French project of co-managing European monetary policy alongside Germany. FeLDSTEIN (1997a: 28) wrote,

"France sees EMU and the stronger political union to which EMU will lead an opportunity for France to be a co-manager of Europe as an equal of Germany rather being dominated by a Germany that has nearly 50 percent more population than France. In the economic sphere, the current domination of European monetary policy by the German Bundesbank would be replaced by the European Central bank at which Germany and France would sit and vote as equals".

The trump card that Mitterrand held was that of France's political position on the issue of German unification following the dissolution of the USSR. In turn, the German chancellor, 
Helmut Kohl, seemed more interested in the problem of the reunification of Germany than in the creation of a single European currency, to the point of being prepared to pay France a price on the issue of the governance of the single currency. So much so that the German Chancellor, to some extent, distanced himself from the positions taken by the Bundesbank, in order to obtain French support for the reunification. The expressions of regret of André SzÁsz (1999, p. 113) were not absent in respect of Kohl's attitude to accepting the acceleration of the European monetary integration process imparted by Mitterrand. As Dyson and Featherstone (ibid: 199) noted, the creation of the European Monetary Union (EMU) responded to the strategic needs of Mitterrand's France. More precisely,

"France would gain by retrieving a measure of influence over economic and monetary policy and the potential to reshape international and European economic and monetary relations on its own terms. In order to identify his Presidency with these gains Mitterrand was prepared to take the domestic political lead in getting acceptance of the difficult concessions that were the price of solving the problem of German monetary power and pursuing Franco-German reconciliation, notably on central bank independence".

For Mitterrand's France, becoming the champion of the single European currency implied radically changing ideological positions stratified over time, partially submerged in a type of radical Keynesianism that was widespread in the political world. For example, France ended up accepting the idea that the aim of a European Central Bank should be that of price stability. Furthermore, Mitterrand, who had always shown a certain hostility towards the independence of the central banks of the respective governments, accepted the idea of independence from European national governments of the 
European Central Bank itself. Meanwhile, the French Trichet, resuming Mitterrand's previous position, in 1990 proposed the criterion according to which the budget deficit could not exceed 3\% of GDP in a given country (DYSON and FEATHERSTONE, 1999: 215); meanwhile, the French government was concerned about the German proposal to introduce sanctions against States with excessive deficits. At the beginning, such sanctions were seen by Mitterrand as a breach of the principle of national sovereignty. The issue that French and German negotiators had to face was the credibility of the commitments made by partner governments. Credibility that, at least in Germany's view, could only improve if the commitments were accompanied by credible threats against defector countries.

\section{France meets Germany}

However, at the time of concluding the negotiations that would give life to the Maastricht Treaty, France proposed a draft Treaty in which the creation of the EMU was based on three principles: a) feasibility, b) democracy; c) the European dimension (Dyson and Featherstone, 1999: 229). The feasibility of the EMU would be ensured by strengthening the ECOFIN policy instruments to ensure economic convergence including sanctions to avoid excessive deficits, the prohibition of debt bailout and deficit financing through the issuance of currency. The French draft converged on the idea of entrusting the governance of prices to a future independent $\mathrm{ECB}$, recognizing a role to ECOFIN in determining the exchange rate policy guidelines.

Democratic legitimacy, according to the French draft, would depend on a "gouvernement économique", without which the European Monetary Union would not be feasible. The European dimension was based on the empowerment of 
the European Council in defining the Community's economic policy guidelines. In this draft emerged both the acceptance of important German positions and the assertion of abstract principles that to a certain extent concealed the French desire to save the role of national governments in relation to economic policy. Aiming to play a hegemonic role in European politics, France made some fundamental concessions to Germany, without which Germany would not accept the euro. One of these was the independence of the ECB, which would have as its mission the defence of price stability. Indeed, France agreed with Germany on the principle that the burden of the budget balance should fall on countries with excessive deficits. This was a type of adaptation of the principle that emerged at Bretton Woods according to which the burden of the adjustment of the trade balance deficit should fall on the countries that have these deficits. At Bretton Woods, it was the deficit of balance of payments, in Maastricht it was the budget deficit.

It must be said that, while France was pursuing vacuous dreams of grandeur, Germany focused its agenda on a few concrete objectives. Among other things, Kohl was able to utilize the well-known difficult relationship between the German government and the Bundesbank and at the very beginning highlighted the non-negotiable points for Germany, where the political and cultural positions against the assignment of the mark to a supranational authority were very strong (Dyson and Featherstone, 1999: 448 ff.).

Faced with France's political pressing and Mitterrand's moral suasion in relation to German expectations on unification, Germany eventually adhered to the French project of rapidly creating the European Central Bank (Feldstein, 1992.). Feldstein's opinion was widely shared by international relations scholars and suggested that France proposed itself as 'hegemon' of the European Union rather than Germany. 
If the goal of French politicians was to build a Franco-German diarchy with French political leadership, the goal of German politicians was, if anything, to orient the financial and economic policy of the European Union towards the German economic and social model in relation to which development was not assured by deficit spending policies, but by policies to increase the competitiveness of national economic systems and the correlated institutional systems. In the diarchy logic, France assumed assuring itself military and political leadership and Germany economic leadership. In the long run, economic strength and the credibility of the economic institutions of Germany demarcated the emergence of a hegemony that was certainly different from that which characterized U.S. hegemony after World War II. FeLdstein (1997a: 29) in this respect wrote

"it is clear that a French aspiration for equality and a German expectation of hegemony are not compatible. But both visions of the future drive their countrymen to support the pursuit of the EMU".

In reality, the equal diarchy entered in crisis due to both the greater growth of the German economy compared to the French and the entry of many Eastern European countries in the European Union that naturally looked to Germany, and certainly not to France, as the guiding country.

\section{The reluctant hegemon}

Yet to be evaluated is whether Germany can consider itself the dominant country of the euro area and whether Germany already considered itself a hegemonic power in the EMS capable of imposing its own vision of monetary policy, as the U.S. did after the end of World War II. In this 
regard, Tommaso PAdoA-Schioppa (2004) raised the question as to whether Germany could play the same role in Europe as the U.S. in the world and if therefore the DM could play the same role as the dollar. The response that Padoa-Schioppa gave is, as it should be, negative and refers to the experience of the U.S., which although powerful, could not sustain the burden arising from exercising hegemonic power in the monetary sphere. Furthermore, PadoA-Schioppa (2004: 148) pointed out that Germany is not the United States and that the weight of the German economy within the EU is not comparable to the weight of the U.S. economy within the world. Consequently, with respect to the mark, "neither Germany nor the other member countries would agree that it has the role that the dollar had in Bretton Woods system" (ibid). In conclusion, PadoA-Schioppa noted that since the U.S. was unable to bear the burden of being the leading country of the Bretton Woods monetary system then such a role is even less likely for Germany.

The other hypothesis is that Germany had a vision of European monetary integration that was widely shared at the stage of negotiating the launch of the Maastricht Treaty. According to PADOA-SCHIOPPA, testimony of this is once again the relatively old debate between 'economists' and 'monetarists'. A debate that the Delors Report had tried to defuse, but which during the negotiations for the single currency swung, at least in part, in favour of the thesis of 'economists'. In this regard, PADOA-Schioppa (2004: 209) wrote,

"I think one can say that there is now agreement on the fact that economic convergence in the form of greater price stability and healthier financial and budgetary conditions should make some progress before the start of the final phase of the union". 
From the above it is clear that among the big European countries, Germany did not have a well-defined political project to economically dominate EU countries through the instrument of a single currency. On the contrary, it did not feel ready for an initiative of this type and sought to curb the enthusiasm of other European countries, starting with France. If anything, France was the country that took the initiative to promote the rapid creation of the single currency and did so by 'blackmailing' the German government on the issue of reunification. France put a strategy into play to achieve general policy objectives, disregarding the objective difficulties in giving birth to a single European currency.

The German government gave in to the French 'blackmail' inasmuch as it was less concerned about the single currency than the unification of the two parts of the country. The German government was entrenched in the operating conditions that would allow the governance of the new European monetary system, namely, determining the rules that such governance should obey. The governments of the major European countries certainly advocated a policy of financial rigour. For example, the Italian delegation declared its close proximity to the Delors Plan and at the same time expressed interest in accepting certain quantitative constraints to ensure budgetary discipline. Dyson and Featherstone wrote that in the final stage of the negotiations, the model of the Bundesbank system was affirmed, "which was, in turn, not so distant from the self-image of the Banca d'Italia" (ibid: 507). On the other hand, they note that the Ciampi, the governor of the Bank of Italy, and his staff were "adherents of the utility of external disciplines" (ibid: 502).

It is worth reflecting on the reason why the credibility of the commitments of the various European countries was sought in the matter of budgetary policy by imposing quantitative constraints on the basic parameters of these policies. 
A complex and delicate construction such as the euro would never have been born if confidence in the partner countries had been called into question by the actual opportunistic behaviour of some these countries. With opportunistic behaviour I intend the propensity to deficit spending policies generated by the propensity to inflationary policies. These two tendencies are generally linked in the sense that countries that normally have a high level of public debt also have a high level of inflation. It is clear that the central and northern European countries, on average with a lower propensity to inflation, were unwilling during the negotiations for the single currency to import inflation from less virtuous countries. The central and northern European countries were unwilling to sustain the real economies of countries with a high propensity to inflation and implementing in turn inflationary policies. The reason lies in the fact that these 'induced' inflationary policies would have had the effect of weakening the competitiveness of stronger European economies in the global market.

To some extent, the debate during the negotiations that led to the Maastricht Treaty echoed some of the content of the debate that took place in Bretton Woods, notwithstanding the obvious distinctions. If at Bretton Woods the debate was focused on identifying who - that is say, the creditor or debtor countries - would have to intervene if some countries manifested structural deficits in their balances of payments, in Maastricht the debate focused on the identification of who among countries with budgets in surplus and those with budgets in deficit - would have to concern themselves with correcting the deficit. The German position prevailed, namely, that deficit countries take action to remedy these positions, also because the governments of countries with a higher propensity to inflation and with greater disorder in their national budgets underestimated the implications of a commitment of this type 
and believed that the constraints contained in the Maastricht Treaty would have altered the collective behaviour in terms of budgetary policies. The European partner countries in the Eurozone made the commitments not so much because of the fiscal will of Germany, but for the underlying sharing of the governance of such an integrated currency area. Consequently, Germany could be regarded, if anything, as a hegemon in the sense of IsHiguro, but cannot be considered a hegemonic country in the sense of Keohane.

\section{References}

Aокi, M. (2001), Toward a Comparative Institutional Analysis, Cambridge, MA, The MIT Press.

Apel, E. (1998), European Monetary Integration.1958-2002, London, Routledge.

Avelãs Nunes, A.J. (2013), “O Euro: das promessas do paraíso às ameaças de austeridade perpétua”, in Boletim de Ciências Económicas”, (LVI), pp. 3-166.

Casprini, F. (1995), L'Economia delle Relazioni Monetarie Internazionali, Roma La Nuova Italia Scientifica.

Catalano, F. (1972), La crisi del sistema monetario internazionale, Milano, Etas Libri.

Cesarano, F. (2006), Monetary Theory and Bretton Woods, Cambridge, UK, Cambridge University Press.

Corden, W. (1972), Essays in International Finance, Princeton, Princeton University Press.

Denem, R. (1972), "Le mirage monétaire européen, son cout et ses aléas”, Recherches économiques de Louvain.

Dixit, A.; Skeath S.; Reiley, D. (2009), Games of Strategy, New York, Norton.

Dyson, K.; Featherstone, K. (1999), The Road to Maastricht, Negotiation Economic and Monetary Union, Oxford, Oxford University Press.

Eichengreen, B. (1989), "Hegemonic Stability Theory of the International Monetary System" in R. Cooper et al (eds.), Can Nations Agree? Issues in International Economic Cooperation, Washington, DC, Brookings Institution, pp. 255-298.

— (1996), Globalizing Capital. A History of the International Monetary System, Princeton, NJ, Princeton University Press. 
Feldstein, M. (1992), “Europe's Monetary Union. The Case against EMU”, The Economist, June 13.

— (1997a), "The Political Economy of the European Economic and Monetary Union: Political Sources of an Economic Liability", Journal of Economic Perspectives (11), n.4, pp. 23-42.

— (1997b), "EMU and International Conflict", Foreign Affairs, (76), n. 6, pp. 60-73.

Fleming, J.M. (1971), “On Exchange Rate Unification”, Economic Journal, vol. 81: 467-488

Gardner, R. N. (1956), Sterling-Dollar Diplomacy in Current Perspective, New York, Columbia University Press.

Giavazzi, F. and Giovannini, A. (1989), Limiting Exchange Rate Flexibility, Cambridge, MA, The MIT Press.

Gilpin, R. (2001), Global Political Economy, Princeton, NJ, Princeton University Press.

Harrod, R.F. (1951), The Life of John Maynard Keynes, London, MacMillan \& Co.

Ishiguro, K. (2003), "Rethinking Theory of Hegemonic Stability: Toward a Theory of Hegemonic Cooperation", Kobe University Economic Review, (49): 19-44.

James, H. (2012), Making the European Monetary Union, Cambridge, MA, Harvard University Press.

Johnson, H. (1972), "Problems of European Monetary Union", in H. Johnson, Further Essays in Monetary Economics, London, Allen \& Unwin, pp. 312-324.

Kebabdjian, G. (1999), Les Théories de l'Economie Politique Internationale, Paris, Editions du Seuil.

Keohane, R: (1984), After Hegemony. Cooperation and Discord in the World Political Economy, Princeton, NJ, Princeton University Press.

Keynes, J.M. (1923), A Tract on Monetary Reform, London, McMillan.

Kouvelakis, S. (2012), "Introduction: The End of Europeanism", in C. Lapavitsas (ed.), Crisis in the Euro Zone, London, Verso.

MaEs, I. (2002), Economic Thought and the Making of European Monetary Union, Cheltenham, Elgar.

Magnifico, G. (1971), "European Monetary Unifications for Balanced Growth: A New Approach", in G. MAGNifico, European Monetary Unification (1972), London, McMillan, pp. 1-42.

Mundell, R. (1961), A Theory of Optimaum Currency Areas", The American Economic Review, n. 4, pp. 657-664.

Padoa-Schioppa, T. (2004), La lunga via per l'Euro, Bologna, Il Mulino.

Pifferi, M.; Porta, A. (2006), La Banca Centrale Europea, Milano, Egea. 
Schelling, T. (1960), The Strategy of Conflict. Cambridge, MA, Harvard University Press.

Skidelsky, R. (2000), John Maynard Keynes. Fighting for Freedom, New York, Viking.

Steil, B. (2013), The Battle of Bretton Woods, Princeton, Princeton University Press.

Strange, S. (1987),'The Persistent Myth of Lost Hegemony", International Organization, 41, n. 4, pp. 259-274.

SzÁsz, A. (1999), The Road to European Monetary Union, Basingstoke, UK, MacMillan Press.

From Bretton Woods to the Euro.

Critical Considerations According to the Hegemonic Stability Approach

Abstract: In this paper a fundamental question is raised: is Germany the hegemonic country in the European Union? The question is not a rhetorical one because political sciences teach us that the EU institutional architecture must depend on the nature of the answer we can offer. The $\mathrm{EU}$ is a coalition of states which hope to obtain increasing performances for their economies through the cooperation of national governments. But we have a problem with the concept of cooperation. When partners have similar economic forces, cooperation may consist in the adoption of shared models of economic policy. But when partners have divergent economic forces, the strongest country among them can assume the role of guarantor of equilibria in the coalition, even with lateral payments. Not always can this function be maintained for a long time, as in the case of the U.S. role in the governance of the international monetary system after Bretton Woods. In the case of the euro, my impression is that Germany cannot guarantee the stability of the system, because she has not sufficient force for a task of this type. zations.

Keywords: monetary systems; monetary policy; international organiMaurizio Mistri

Dipartimento di Scienze Economiche e Aziendali "Marco Fanno" — Università di Padova 